\title{
APLIKASI INFORMATION RETRIEVAL UNTUK PENCARIAN DOKUMEN LAPORAN PENELITIAN
}

\author{
Indri Tri Hapsari ${ }^{1}$, Banni Satria Andoko ${ }^{2}$, Cahya Rahmad ${ }^{3}$ \\ 1,2 Jurusan Teknik Elektro, Program Studi Teknik Informatika, Politeknik Negeri Malang \\ 1indri.tri.hapsari@gmail.com, ${ }^{2}$ banniandoko@gmail.com, ${ }^{3}$ cahyarahmad@gmail.com
}

\begin{abstract}
Abstrak
Information retrieval atau temu kembali informasi merupakan sistem pencarian untuk menemukan kembali sebuah informasi. Penelitian ini bertujuan untuk merancang dan mengimplementasikan sistem pencarian dokumen laporan penelitian sehingga dapat mempermudah dalam menemukan kembali dokumen yang diinginkan oleh pengguna. Text mining digunakan untuk mengolah teks atau preprocessing didalam dokumen sebagai kata kunci dan perhitungan termfrequency - inverse document frequency (TF-IDF) sebagai metode pembobotan setiap kata dalam dokumen sesuai dengan kata kunci yang diinputkan pengguna. TF-IDF dipengaruhi oleh frekuensi kemunculan kata pada sebuah dokumen dan frekuensi dari dokumen yang memiliki kata tersebut sehingga jika diimplementasikan sistem ini dapat menemukan kembali informasi dari dokumen laporan penelitian yang disimpan secara cepat dan efisien, serta dari hasil pencarian dapat diurutkan berdasarkan bobot informasinya.Hasil dari penelitian ini menunjukkan bahwa pembobotan kata dengan menggunakan TFIDF dapat me-retrieve dokumen yang relevan dengan query masukan pengguna.
\end{abstract}

Kata kunci :information retrieval, text mining, $T F-I D F$, pencarian

\section{Pendahuluan}

Seiring dengan perkembangan informasi, masalah utama telah bergeser dari cara mengakses informasi menjadi memilih informasi utama yang berguna secara selektif. Pencarian atau pemilihan informasi ini tidak mungkin dilakukan secara manual karena kumpulan informasi yang sangat besar, banyak, dan beragam. Dibutuhkan suatu sistem otomatis untuk membantu user (pengguna) dalam menemukan informasi. Search engine (mesin pencari) dapat mengatasi permasalahan tersebut secara efektif. Setiap search engine menggunakan proprietary algorithm untuk menciptakan indeks-indeks yang ditampilkan dalam bentuk hasil pencarian (Sarwono, 2010:1).

Sistem pencarian dokumen umumnya menampilkan hasil pencarian berdasarkan kata kunci (keywords) dan peringkatnya yang ditampilkan dalam daftar yang panjang. Sebagian search engine masih menggunakan metode tersebut dan memiliki karakteristik pencarian dokumen yang memiliki tingkat kecocokan rendah. Pencarian dokumen teks merupakan permasalahan yang mendasar dan penting. Didalam dokumen teks, tulisan yang terkandung merupakan bahasa dengan struktur yang kompleks dan memuat jumlah kata yang banyak. Dari permasalahan tersebut dikembangkanlah suatu ilmu yang diberi nama temu-kembali informasi (information retrieval).

Temu-kembali informasi berhubungan dengan penyimpanan, struktur dan akses dari dokumen-dokumen yang bertujuan untuk memudahkan pencarian suatu informasi. Representasi dari dokumen itu diharapkan harus mudah diakses oleh pengguna untuk mendapatkan informasi. Tujuan dari penelitian ini adalah mencoba menerapkan konsep temu-kembali informasi yang di terapkan di dalam sebuah sistem penyimpanan dokumen teks berbasis web. Dengan menerapkan konsep tersebut, diharapkan sistem dapat melakukan pencarian dokumen berdasarkan informasinya secara cepat dan mengetahui tingkat akurasi hasil pencarian dengan metode pembobotan kata TF-IDF (TermFrequencyInverse DocumentFrequency).

\section{Metode}

\subsection{Information Retrieval (Temu-Kembali} Informasi)

Temu-kembali informasi atau Information Retrieval (IR) adalah aktifitas utama yang dilakukan oleh sebuah penyedia informasi atau pusat pelayanan informasi, termasuk perpustakaan dan jenis dari layanan lainnya yang menyediakan informasi kepada masyarakat umum. Menurut sebuah ensiklopedia, temu-kembali informasi adalah seni dan ilmu dalam pencarian informasi di sekumpulan dokumen-dokumen, pencarian informasi di dokumen itu sendiri, pencarian metadata yang menjelaskan sekumpulan dokumen, atau pencarian di dalam basis data (Wikipedia, 2010). Temu kembali informasi 
berhubungan dengan representasi informasi, data penyimpanan, pengorganisasian, dan akses untuk informasi tersebut (Baeza-Yates, 1999). Nantinya hasil akhir dari temu-kembali informasi adalah sebuah sistem yang dapat melakukan penemuan-kembali informasi atau disebut sistem temu-kembali informasi (Nadirman,2006).

\subsection{Text Mining}

Text Mining adalah suatu proses yang bertujuan untuk menemukan informasi dengan memproses dan menganalisa data dalam jumlah yang besar. Dalam menganalisa sebagian atau keseluruhan unstructured text, text mining mencoba untuk mengasosiasikan satu bagian teks dengan yang lainnya berdasarkan aturan tertentu. Text mining memiliki definisi menambang data yang berupa teks dimana sumber data biasanya didapatkan dari dokumen, dan tujuannya adalah mencari kata-kata yang dapat dilakukan analisa keterhubungan antar dokumen (Barakbah, 2013).

\subsection{Pembobotan TF-IDF}

Baeza-Yates dan Ribeiro-Neto (1999), menyebutkan bahwa pembobotan TF-IDF terdiri dari dua faktor, yaitu:

1. TF (termfrequency)

TF adalah frekuensi kemunculan suatu istilah $f_{i}$ di dalam sebuah dokumen $d_{j}$ dibandingkan dengan frekuensi istilah $f_{l}$ yang sering muncul pada dokumen itu. Jika dimasukkan dalam rumus matematika didapatkan:

$$
f_{i, j}=\frac{\text { freq }_{i, j}}{\max _{l} \text { freq }_{l, j}}
$$

Gambar 1. Rumus term frequency

2. IDF (inverse document frequency)

$I D F$ adalah frekuensi kemunculan suatu istilah $f_{i}$ di dalam seluruh dokumen. Penggunaan faktor IDF didasarkan pada istilah yang muncul pada setiap dokumen tidak memberikan suatu ciri khusus untuk menentukan dokumenyang relevan dari yang tidak relevan. Jika jumlah seluruh dokumen di dalam sistem dinyatakan dengan nilai $N$ dan jumlah dokumen yang memiliki istilah $f_{i}$ tersebut dinyatakan dengan ni, maka nilai $I D F_{i}$-nya dapat dinyatakan dengan:

$$
i d f_{i}=\log \frac{N}{n_{i}}
$$

Gambar 2. Rumus inverse document frequency
Keterangan :

$I D F=$ inverse document frequency

$N=$ jumlah kalimat yang berisi term $(\mathrm{t})$

$n_{i}=$ jumlah kemunculan kata (term)

terhadap $d_{j}$

Faktor pembobotan untuk tiap kata dalam dokumen didefinisikan sebagai kombinasi termfrequency dan inverse document frequency. Dari dua faktor tersebut maka pembobotan TF-IDF dapat dinyatakan dengan:

$$
w_{i, j}=f_{i, j} \times \log \frac{N}{n_{i}}
$$

Gambar 3. Rumus $T F-I D F$

$$
w_{i j}=t f_{i j} \times i d f_{j}
$$

Gambar 4. Rumus pembobotan $T F-I D F$ Keterangan:

$w_{i j} \quad=$ nilai bobot kata ke $j$ dari dokumen $i$

$t f_{i j} \quad=$ termfrequency, yakni jumlah kemunculan kata $t_{\mathrm{j}}$ dalam dokumen $D_{i}$

$d f_{j} \quad=$ document frequncy, yakni jumlah dokumen yang mengandung $t_{j}$

$I D F_{j} \quad=\log \left(\frac{d}{n i}\right)$ dengan d adalah jumlah semua dokumen dalam koleksi. $I D F_{\mathrm{j}}$ adalah inverse document frequency (Anistyasari dkk, 2012).

Pada Metode ini pembobotan kata dalam sebuah dokumen dilakukan dengan mengalikan nilai $T F$ dan IDF. Pembobotan diperoleh berdasarkan jumlah kemunculan term dalam kalimat $(T F)$ dan jumlah kemunculan term pada seluruh kalimat dalam dokumen (IDF). Bobot suatu istilah semakin besar jika istilah tersebut sering muncul dalam suatu dokumen dan semakin kecil jika istilah tersebut muncul dalam banyak dokumen (Fatkhul, 2011).

Kemudian baru melakukan proses pengurutan (sorting) nilai kumulatif dari W untuk setiap kalimat. Tiga kalimat dengan nilai W terbesar dijadikan sebagai hasil dari ringkasan atau sebagai output dari peringkasan teks otomatis (Sarno, dkk, 2012).

\subsection{Rancangan Sistem}

Fokus penelitian ini adalah bagaimana mengimplementasikan sistem pencarian dokumen secara otomatis dan efisien. Sistem temu kembali informasimemiliki dua tahapan besar, yaitu melakukan preprocessing terhadap database dan kemudian menerapakan metode tertentu untuk menghitung relevansi antara dokumen di dalam database yang telah di preprocess dengan query pengguna.

Proses preprocessing meliputi proses tokenisasi atau pemotongan kata dalam suatu kalimat, 
filtering atau proses penyaringan kata hasil tokenisasi dimana kata yang tidak relevan dibuang seperti stoplist, stemming merupakan proses memecahkan setiap imbuhan suatu kata menjadi kata dasar, dan termweighting atau pembobotan kata.

Stemming adalah tahapmencari kata dasar dari setiap kata hasil filtering. Digunakan untuk mereduksi bentuk term untuk menghindari ketidakcocokan sehingga dapat mengurangi recall. Pembobotan kata (termweighting) dilakukan dengan menghitung frekuensi kemunculan term dalam dokumen. Frekuensi kemunculan (termfrequency) merepresentasikan isi dari suatu dokumen. Semakin besar kemunculan suatu term dalam dokumen akan memberikan nilai kesesuaian yang semakin besar. Selanjutnya akan dilakukan perangkingan berdasarkan bobotnya, dimana bobot yang tertinggi adalah yang dapat diasumsikan sebagai hasil pengujian.

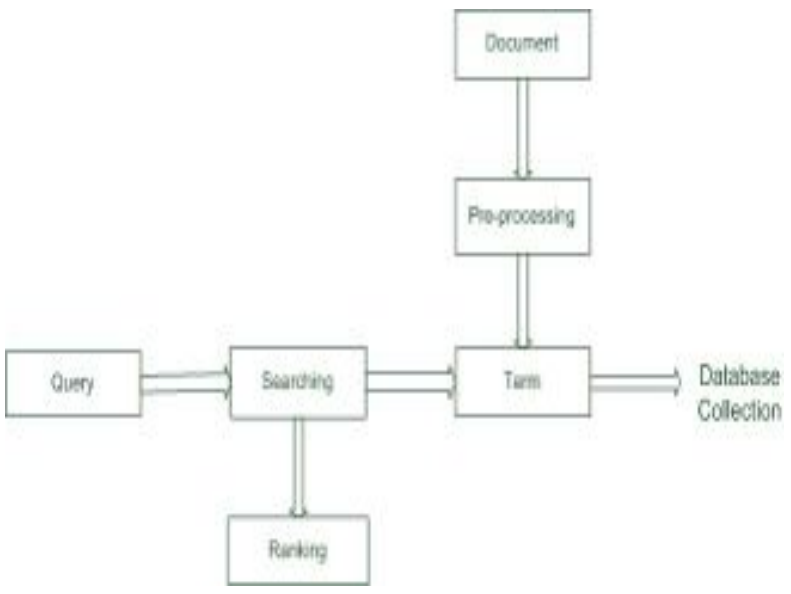

Gambar 5. Block Diagram IR

\subsection{Pemodelan Sistem}

\section{Use Case Diagram}

Pada sistem dua aktor yaitu user dan administrator. Administrator melakukan login sesuai dengan hak yang diperolehnya. Kemudian admin dapat meng-upload dokumen laporan penelitian dalam bentuk .docx. Admin dapat mengolah dokumen yang ada pada database. User memiliki hak untuk memasukkan kata kunci pada kolom pencarian untuk melakukan pencarian dokumen laporan penelitian dan mengunduh dokumen laporan tersebut.

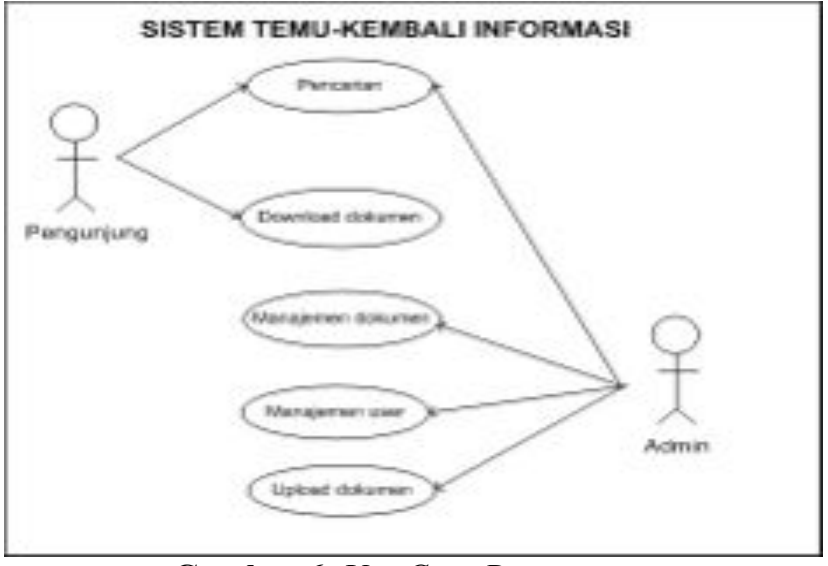

Gambar 6. Use Case Diagram

Data Flow Diagram

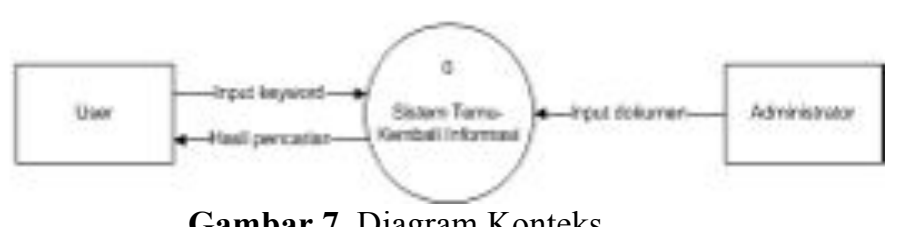

Gambar 7. Diagram Konteks

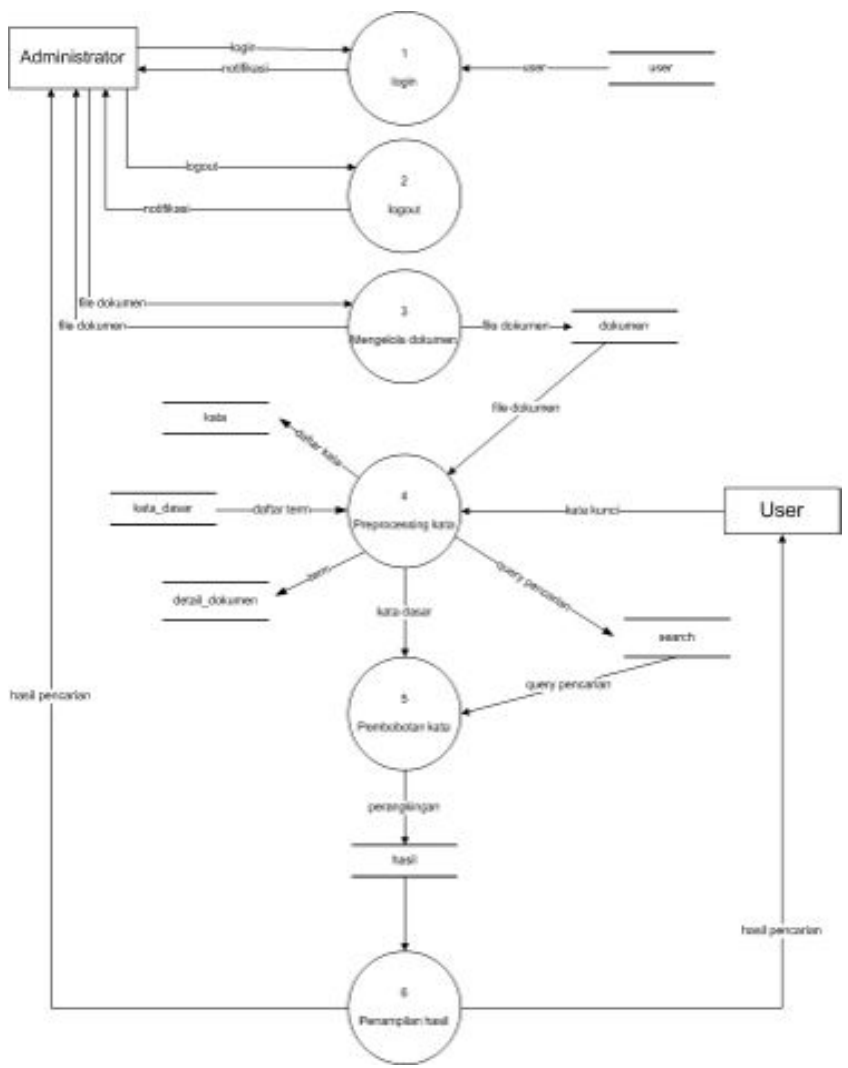

Gambar 8. DFD Level 1

\subsection{Rancangan Interface}

Pada rancangan interface, terdapat menu Home yang menampilkan kolom pencarian dan kolom hasil pencarian. User memasukkan kata kunci pada kolom pencarian 
yang menjadi dasar dalam perhitungan untuk merangking dokumen yang paling relevan.Data dokumen memuat arsip dokumen yang terdapat pada database.

\section{Hasil}

\subsection{Implementasi Basis Data}

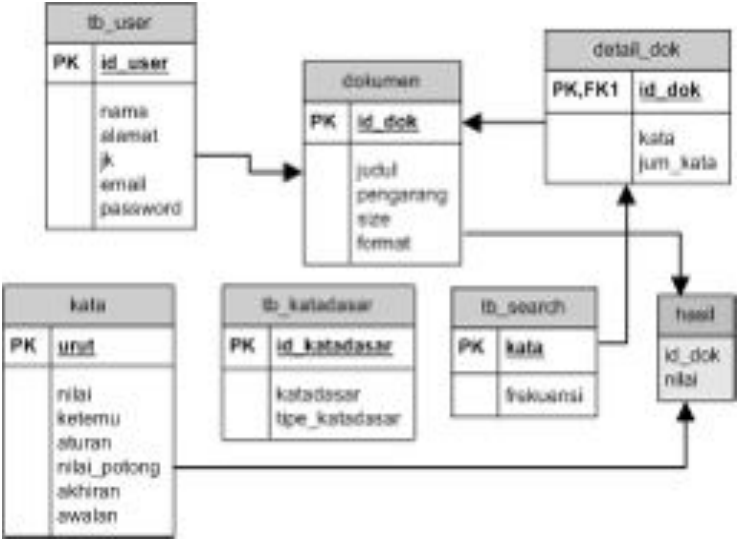

Gambar 9. Database Diagram Aplikasi IR

\subsection{Implementasi Antarmuka}

Berikut merupakan tampilan dari Aplikasi Information Retrieval. Terdapat menu Home yang berisi kolom pencarian, Arsip untuk melihat koleksi dokumen, Login untuk administrator.

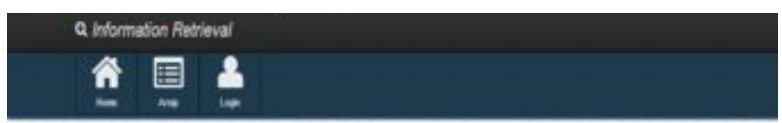

Selamat Datarg

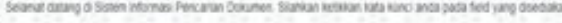

e Nocarin Dohinat

a corits

$\operatorname{con}$

Gambar 10. Tampilan Home Aplikasi IR

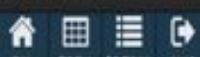

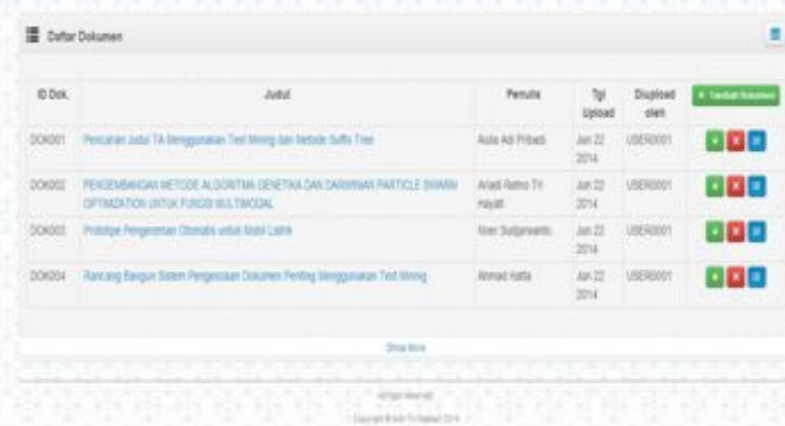

Gambar 11. Tampilan Data Dokumen

\section{合田焉}

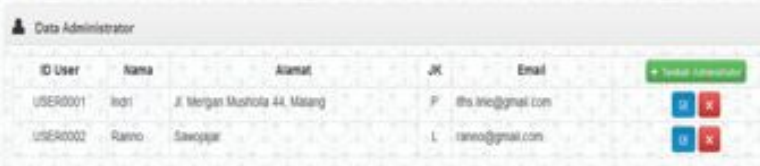

Gambar 12. Tampilan Data User

\section{Pembahasan}

\subsection{Proses Tokenisasi}

Hasil implementasi information retrieval saat proses preprocessing dokumen dan pembobotan $T F-I D F$ adalah me-retrieve dokumen atau menemukan kembali dokumen yang diinginkan. Berikut merupakan pengujian tokenisasi dan filtering dengan memberikan inputan kalimat yang mengandung tanda baca dan kata yang termasuk stoplist.

Teks Awal : "Rancang Bangun Sistem Informasi Pembuatan Katalog Online."

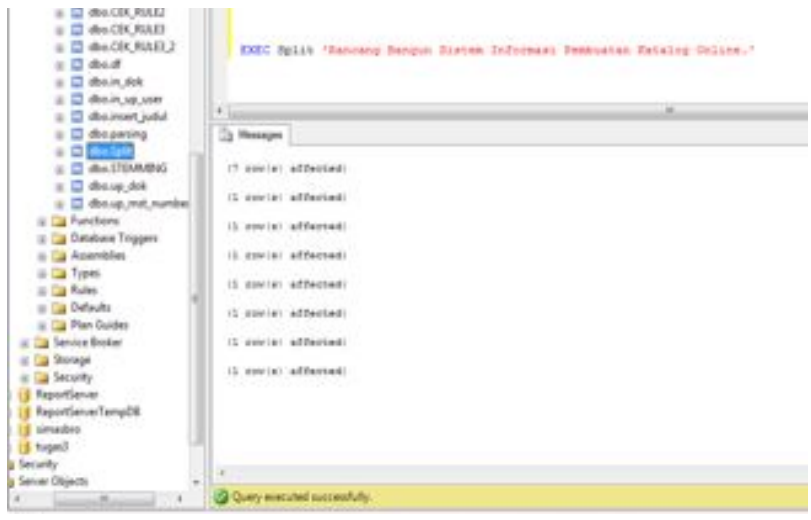

Gambar 13.Hasil Pengujian Tokenisasi

\subsection{Proses Filtering}

Teks Awal : "Rancang Bangun Sistem Informasi Pembuatan Katalog Online.”

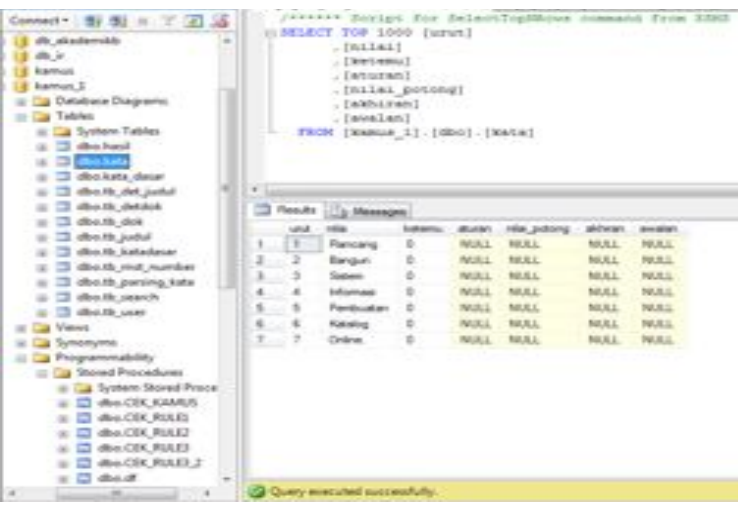

Gambar 14.Hasil Pengujian Filtering 


\subsection{Proses Stemming}

Kalimat dalam Bahasa Indonesia sering tersusun dari kata-kata yang berimbuhan. Stemming merupakan sebuah proses pengembalian kata-kata tersebut ke bentuk dasar. Pada pengujian ini, metode stemming yang digunkan adalah algoritma stemming Nazief-Adriani dan akan diberikan inputan suatu kalimat yang tersusun dari kata berimbuhan. Hasil yang benar pada pengujian ini adalah jika kata berimbuhan dalam kalimat inputan berubah ke bentuk dasar.

Pada Gambar 15 menunjukkan bahwa katakata yang sudah di tokenisasi dan di filtering dikembalikan ke bentuk dasar.

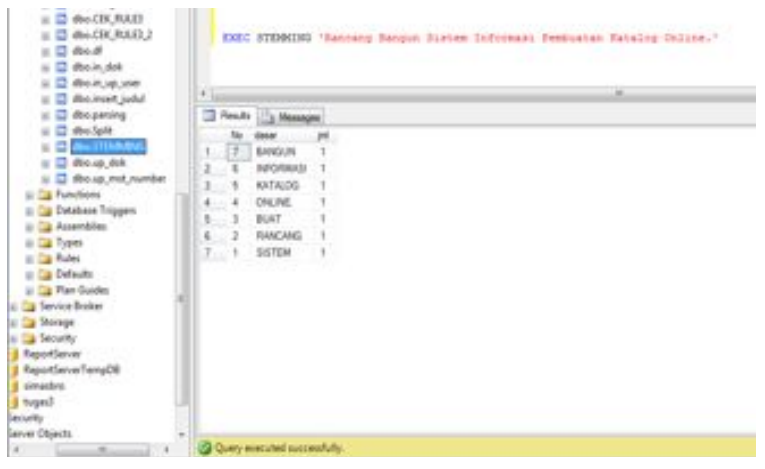

Gambar 15.Hasil Pengujian Stemming

\subsection{Pembobotan TF-IDF}

\section{a. Perhitungan $\boldsymbol{T F}$}

Kata kunci : Rancang Bangun Sistem Informasi Pembuatan Katalog Online

\begin{tabular}{|c|c|c|c|c|c|c|c|c|c|c|c|c|c|}
\hline uil & wi. & tow & Weit & Wus & WWI & toul & WeV & weil & Wiv & weil & wais & Wet & whil \\
\hline Was & 1 & 1 & 1 & 1 & 1 & 1 & 1 & 1 & 1 & 1 & 1 & 1 & 1 \\
\hline biat & 1 & I & 1 & I & 1 & 1 & 1 & 1 & 1 & 1 & 1 & 1 & 1 \\
\hline Nowes & 1 & 1 & 1 & 1 & 1 & 1 & 4 & 1 & 1 & i & 1 & 1 & 1 \\
\hline atson & II & 1 & 1 & 1 & 1 & 1 & 1 & 1 & 1 & 1 & 1 & 1 & 1 \\
\hline owei & 1 & 1 & 1 & 1 & $i$ & 1 & 1 & 1 & 1 & 1 & 1 & 1 & 1 \\
\hline Hows & 1 & 1 & 1 & 1 & 1 & 1 & 1 & 1 & 1 & 1 & 1 & 1 & 1 \\
\hline mo & 1 & $i$ & 1 & 1 & 1 & 1 & $i$ & 1 & 1 & 1 & 1 & 1 & 1 \\
\hline
\end{tabular}

Gambar 16. Hasil Perhitungan $t f$

Setelah hasil perhitungan tf didapatkan, langkah selanjutnya adalah perhitungan idf tiap term untuk menghitung bobot term.

\section{b. Perhitungan IDF}

Rumus idf:

$$
i d f=(1 / d f)
$$

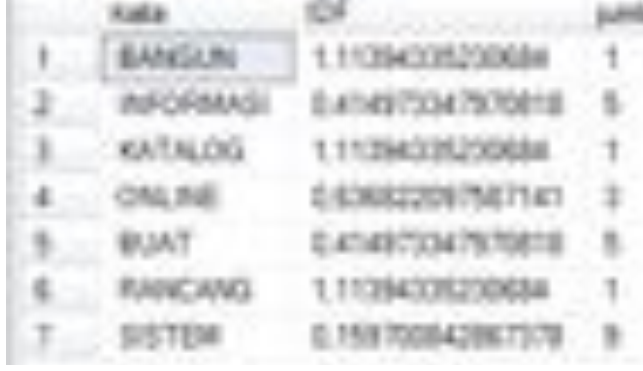

Gambar 17.Hasil Perhitungan idf

Selanjutnya, setelah nilai $t f$ dan $i d f$ telah didapatkan, kemudian dimasukkan dalam perhitungan $t$-idfweighting untuk menghitung bobot hubungan suatu term di dalam dokumen.

\section{c. Perhitungan $T F-I D F$}

Rumus pembobotan $t f-i d f$ :

$$
\boldsymbol{W}_{t, d}=t f_{t, d} * i d f_{t}
$$

\begin{tabular}{|c|c|c|c|c|c|c|c|c|c|c|c|c|c|c|}
\hline & in & tres & 1001 & 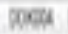 & 1009 & (6) & tCen & WEH & DEII & DEY & DEE & 6027 & क्था & Dell \\
\hline 1 & WON & 1 & 1 & 1 & 1 & IXI & 1 & 1 & 1 & 1 & 1 & 1 & 1 & 1 \\
\hline ? & Wit & 1 & 1 & 1 & 1 & 108. & 1 & 14. & 124 & 134 & 0 & In. & 1 & 0 \\
\hline ) & NonWW & $134 N$ & 1 & 183. & III) & $20 \%$ & 1 & ¿1ब. & 1 & 1 & 0 & 1 & 1 & 0 \\
\hline 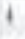 & STLO & $12 \times 13$ & 1 & 1 & 1 & 1 & 1 & 1 & 1 & 1 & 1 & 1 & 1 & 1 \\
\hline 1 & WH & $24 \times 1$ & 1 & 1 & 1 & 24. & 1 & 1 & 1 & 1 & 0 & Un & 1 & 1 \\
\hline I & Nowd & 1 & 1 & 1 & I & (19). & 1 & 1 & 1 & 1 & 0 & 1 & 1 & 1 \\
\hline 1 & MII & 1 & th & thi. & $i$ & IXI. & teit. & th. & $t$ & $t$ & 60 & tin & Ifa & $4 \pi$ \\
\hline & loik.jid & istil & th & 164 & 14 & vill. & IBi & i咸 & $1 \mathrm{ai}$ & its & 60. & 26. & ia & 127 \\
\hline
\end{tabular}

$\mathrm{W}=$ bobot dokumen ke-d terhadap kata ke-t

Gambar 18. Hasil Perhitungan $T F-I D F$

\section{d. Hasil Aplikasi}

Aplikasi menemu-kembalikan dokumen yang relevan dengan kata kunci masukan pengguna

\begin{tabular}{|c|c|c|}
\hline Na & bat & Nand \\
\hline 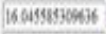 & 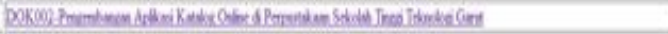 & Spirem \\
\hline 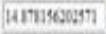 & 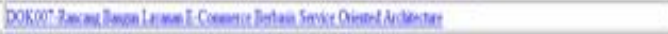 & Alis NShata \\
\hline 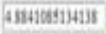 & 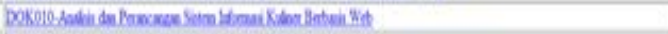 & Wha Bulna \\
\hline 2666549699 & 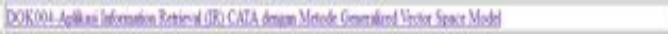 & Himbir Baymin \\
\hline 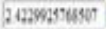 & 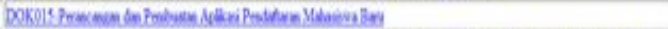 & Nes Haria \\
\hline $12+1+666^{*} 43999$ & 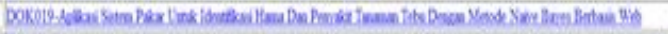 & Araliesta \\
\hline Laweotings & 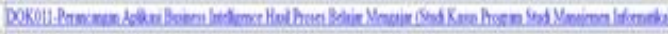 & Bad Hinim \\
\hline 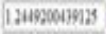 & 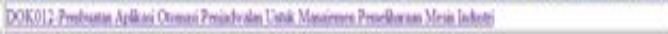 & Aathond \\
\hline DISWUESHIG & 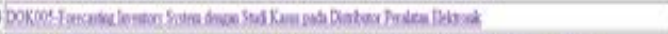 & Autru lladipo \\
\hline 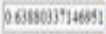 & 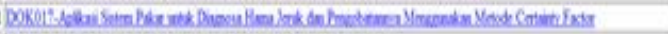 & liod delath \\
\hline p63963) & 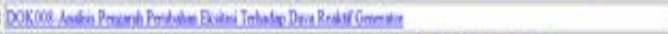 & $\lim \operatorname{Rede}$ \\
\hline 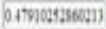 & 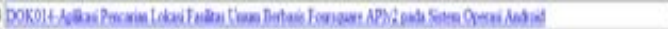 & W kndean \\
\hline 0.3194616944\% & 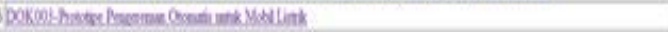 & Na Sectirunat \\
\hline
\end{tabular}
dalam sebuah daftar dokumen.

Gambar 19. Halaman Hasil Pencarian

Dokumen yang memiliki bobot paling tinggi adalah DOK002 dengan total bobot TF-IDF sebesar 16,04. Selain itu, aplikasi juga menemukembalikan dokumen yang relevan dengan kata kunci masukan. 


\section{Kesimpulan dan Saran}

\subsection{Kesimpulan}

Setelah melalui tahap implementasi dan uji coba, maka dapat ditarik kesimpulan:

1. Sistem temu-kembali informasi yang dibuat dapat mencari informasi dari isi file dokumen yang disimpan di dalam sistem. Dokumen di dalam sistem temu-kembali informasi yang dikembangkan melalui beberapa tahapan prapemrosesan dokumen, yaitu tokenisasi, filtering, dan penggunaan stemming.

2. Pada proses pencarian agar sistem dapat menemu-kembalikan dokumen yang relevan maka, kata kunci melalui beberapa tahapan pemrosesan yaitu tokenisasi, filtering, stemming, dan pembobotan kata dengan menggunakan metode $t f-i d f$ untuk mendapatkan rangking berdasarkan nilai bobot setiap dokumen yang akan dicari.

\subsection{Saran}

Saran penulis yang diusulkan untuk penelitian dan pengembangan sistem temu-kembali informasi berikutnya yaitu, dalam temu-kembali informasi, belum cukup hanya mendapatkan dokumen yang relevan. Sistem harus dapat mendapatkan dokumen relevan dan tidak mendapatkan dokumen yang tidak relevan, maka sistem perlu dilakukan pengembangan setelah melakukan pembobotan kata yaitu pengurutan dokumen dengan menggunakan metode model ruang vektor dan atau model probabilistik.

\section{Daftar Rujukan}

Amin, Fatkhul. 2011: Implementasi Search Engine (Mesin Pencari) Menggunakan Metode Vector Space Model, Vol. V No. 1, Hal 4548, Dinamika Teknik.

Baeza-Yates, Ricardo., Ribeiro-Neto, Berthier. 1999 : Modern Information Retrieval, ACM Press Books, New York.

Barakbah, Ali Ridho.2013. Text Mining. EEPISITS, Surabaya.

Hatta, Ramadijanti. N, Helen. A, 2010: Rancang Bangun Sistem Pengelolaan DokumenDokumen Penting Menggunakan Text Mining.

Nadirman, Firnas. 2006: Sistem Temu-Kembali Informasi dengan Metode Vector Space Model pada Pencarian File Dokumen Berbasis Teks. Yogyakarta, Indonesia: Universitas Gadjah Mada.

Sarno, R., Anistyasari, Y. dan Fitri, R. 2012: SEMANTIC SEARCH Pencarian Berdasarkan Konten, Penerbit ANDI, Yogyakarta.

Sarwono, Jonathan. 2010: SEARCH ENGINE, Penerbit ANDI, Yogyakarta.

Wikipedia, 2014, Sistem Temu-Kembali Informasi, EnsiklopediaBebas http://id.wikipedia.org/wiki/Sistem_temu_ balik_informasi Wikipedia [diakses pada 10 Mei 2014] 